\title{
Skala produkcji gospodarstw mlecznych a jej opłacalność
}

\section{Wstęp}

Istotą przedsiębiorczości rolnika jest umiejętność maksymalnego pomnożenia posiadanych pieniędzy, co sprowadza się do takiego zorganizowania produkcji, by osiagnąć jej maksymalną opłacalność. Zagadnienie to nabiera znaczenia, gdy w gospodarstwie istnieje już specjalistyczny majątek trwały, np. związany z produkcją mleka, i powinien być wykorzystywany.

\section{Cel, zakres i metoda badań}

Celem głównym badań było określenie zróżnicowania opłacalności produkcji mleka oraz próba ustalenia czynników determinujących poziom tej opłacalności. Istotnym elementem zagadnienia była skala produkcji mleka $\mathrm{w}$ gospodarstwach specjalistycznych, zarówno w odniesieniu do opłacalności produkcji, jak i nadwyżki bezpośredniej.

W prezentowanych badaniach ograniczono ich zasięg. W $1996 \mathrm{r}$. w sposób celowy do badań przyjęto makroregion środkowy, obejmujący byłe województwa: łódzkie, skierniewickie, piotrkowskie, sieradzkie i płockie. Makroregion środkowy charakteryzuje się centralnym położeniem, przeciętnymi warunkami przyrodniczymi oraz zbliżoną do średniej krajowej wielkością gospodarstw.

Wybór gospodarstw do badań został dokonany jednorazowo, objęto nimi wszystkie gospodarstwa w makroregionie środkowym, które 1 stycznia $1997 \mathrm{r}$. posiadały więcej niż $10 \mathrm{krów}$ mlecznych. Subiektywnie przyjęto, że producenci, którzy mają kilkanaście i więcej krów, są bardziej zaangażowani w tę produkcję i są bardziej doświadczeni aniżeli producenci posiadający kilka krów.

"Badania wykonano w ramach grantu KBN 3 P06 R 04724. 
Materiał źródłowy stanowiły:

- dane statystyki masowej,

- opisy 157 badanych gospodarstw w ramach opracowanego przez autora kwestionariusza,

- karty technologiczne dla działalności roślinnych w produkcji pasz objętościowych.

W badaniu czynników różnicujących opłacalność produkcji mleka wykorzystano metody statystyki opisowej, tabelarycznej i matematycznej, w tym rachunek regresji prostoliniowej prostej i wielorakiej oraz rachunek korelacji. Zastosowano również elementy analizy kluczowych czynników sukcesu (KCS).

W analizie materiałów szczególną rolę, ze względu na tematykę badań, odgrywa relacja wartości produkcji potencjalnie towarowej do kosztów bezpośrednich. W pracy relację tę określono jako wskaźnik opłacalności bezpośredniej.

Wob $=$ Wartość produkcji potencjalnie towarowej/Koszty bezpośrednie

Pojęcie wskaźnika opłacalności bezpośredniej dobrze obrazuje konkurencyjność ekonomiczną danej działalności w gospodarstwie oraz świadczy o przedsiębiorczości producenta. Wskaźnik ten umożliwia wybór i zwiększenie tej produkcji, w rezultacie której następuje maksymalne zwielokrotnienie zaangażowanych środków pieniężnych w postaci kosztów bezpośrednich. W przypadku niedoboru tych środków w gospodarstwie wskaźnik opłacalności bezpośredniej może stanowić kryterium celu gospodarowania. Dotyczy to sytuacji, gdy suma posiadanych środków jest czynnikiem w minimum.

Wskaźnik opłacalności bezpośredniej może zyskiwać na znaczeniu i w ekonomice gospodarstw rolniczych, oprócz relacji nadwyżki bezpośredniej na: gospodarstwo, 1 szt., 1 ha lub 1 rbh, może decydować o wyborze rodzaju i wielkości podejmowanej produkcji. $Z$ uwagi na pominięcie kosztów pośrednich i alternatywnych wskaźnik opłacalności bezpośredniej dobrze obrazuje efekt zróżnicowania technologii wytwarzania tego samego towaru w różnych gospodarstwach, co było szczególnie istotne w prowadzonych badaniach.

Wartość produkcji potencjalnie towarowej, niezbędną do obliczenia wskaźnika opłacalności bezpośredniej, ustalono przez pomnożenie cen skupu przez ilość sprzedawanego mleka w poszczególnych klasach jakości oraz dodanie przychodów ze sprzedaży bezpośredniej mleka, a także sprzedaży cieląt, jałówek hodowlanych, wybrakowanych krów, dodano również wartość spożycia własnego.

Koszty pasz treściwych własnych obliczono na podstawie cen targowiskowych, a do kosztów bezpośrednich w produkcji pasz objętościowych zaliczono koszty: materiału siewnego, nawozów mineralnych, środków ochrony roślin, usług (w tym transportowych), najmu siły roboczej, własnej siły pociagowej i własnego transportu. 
Koszty siły pociągowej liczono według zużycia paliwa, olejów i smarów. Nakłady oleju napędowego na $1 \mathrm{KMh}$ wynoszące 0,08 kg [Józwiak 1988] powiększono o $10 \%$ z tytułu zużycia olejów i smarów.

Do kosztów bezpośrednich w produkcji mleka zaliczono koszty: pasz objettościowych oraz zbioru ścioły, pasz treściwych własnych, pasz z zakupu, transportu wewnętrznego, energii elektrycznej, opału, wody, środków czystości, leków i obsługi weterynaryjnej, inseminacji, zakupu jałówek hodowlanych, usług transportowych na rzecz produkcji mleka, pracy najemnej przy produkcji mleka, utrzymania środków trwałych związanych wyłącznie z produkcją mleka i ubezpieczenia stada.

\section{Nadwyżka i opłacalność bezpośrednia w świetle skali produkcji}

Dla celów analitycznych wyodrębniono pięć grup gospodarstw. Grupa I to gospodarstwa osiaggające w ciągu roku nadwyżkę bezpośrednią z produkcji mleka do kwoty 12 tys. zk, a zatem do 1 tys. zł miesięcznie, grupa II - od 12001 do $25000 \mathrm{zł}$, III - $25001-50000 \mathrm{zł}, \mathrm{IV}-50001-100000 \mathrm{zł}$, grupa V- powyżej 100 tys. zł (tab. 1, rys. 1).

W badanych gospodarstwach skalę produkcji mierzono:

- liczbą utrzymywanych krów mlecznych,

- ilością mleka wyprodukowanego w ciągu roku,

- wartością produkcji towarowej mleka,

- wartością produkcji towarowej mleka i produkcji sprzężonej, do której zaliczono wartość spożycia własnego (mleko, cielęcina, wołowina), sprzedaży cieląt, jałówek hodowlanych i wybrakowanych krów.

W latach 1997-2001 wraz ze wzrostem liczby krów mlecznych, rocznej produkcji mleka, jej wartości towarowej i wartości wyprodukowanego mleka z produkcją sprzężoną rosła roczna nadwyżka bezpośrednia z produkcji mleka.

$\mathrm{W}$ grupach od I do IV znalazły się typowe gospodarstwa rodzinne, a w grupie V gospodarstwa uspołecznione lub funkcjonujące na ich bazie. Należy podkreślić, że w grupach I-IV wraz ze wzrostem nadwyżki bezpośredniej rosła również opłacalność bezpośrednia, co świadczy o tym, że możliwości wzrostu nadwyżki bezpośredniej w tych gospodarstwach nie zostały jeszcze wykorzystane. Istnieje zatem celowość dalszej intensyfikacji produkcji mleka w typowych gospodarstwach rodzinnych. 


\section{Tabela 1}

Nadwyżka i opłacalność bezpośrednia a skala produkcji mleka

\begin{tabular}{|l|c|c|c|c|c|}
\hline \multirow{2}{*}{$\begin{array}{l}\text { Grupy gospodarstw } \\
\text { o rocznej nadwyżce } \\
\text { bezpośredniej } \\
\text { z produkcji mleka } \\
\text { [zł] }\end{array}$} & $\begin{array}{c}\text { opłacal- } \\
\text { ność } \\
\text { bezpo- } \\
\text { średnia }\end{array}$ & $\begin{array}{c}\text { liczba } \\
\text { krów } \\
\text { [szt.] }\end{array}$ & $\begin{array}{c}\text { Srodukcja } \\
\text { mleka [l] }\end{array}$ & $\begin{array}{c}\text { wartość } \\
\text { wyprodu- } \\
\text { kowanego } \\
\text { mleka [zł] }\end{array}$ & $\begin{array}{c}\text { wartość } \\
\text { wyproduko- } \\
\text { wanego mle- } \\
\text { ka wraz } \\
\text { zrodukcją } \\
\text { sprzéżoną } \\
\text { [zł] }\end{array}$ \\
\hline $\begin{array}{l}\text { do 12 000 } \\
\text { grupa I }\end{array}$ & 1,30 & 12,9 & 57753 & 41409 & 46222 \\
\hline $\begin{array}{l}12001-25000 \\
\text { grupa II }\end{array}$ & 2,24 & 13,6 & 61007 & 43699 & 55383 \\
\hline $\begin{array}{l}25001-50000 \\
\text { grupa III }\end{array}$ & 3,06 & 14,6 & 71968 & 51438 & 68648 \\
\hline $\begin{array}{l}50 \text { 001-100 000 } \\
\text { grupa IV }\end{array}$ & 3,55 & 18,0 & 104512 & 79526 & 107249 \\
\hline $\begin{array}{l}>100 ~ 000 \\
\text { grupa V }\end{array}$ & 2,41 & 91,7 & 541403 & 412701 & 529218 \\
\hline Ogółem & 3,14 & 18,4 & 98944 & 77410 & 98058 \\
\hline
\end{tabular}

Źródło: Badania własne.

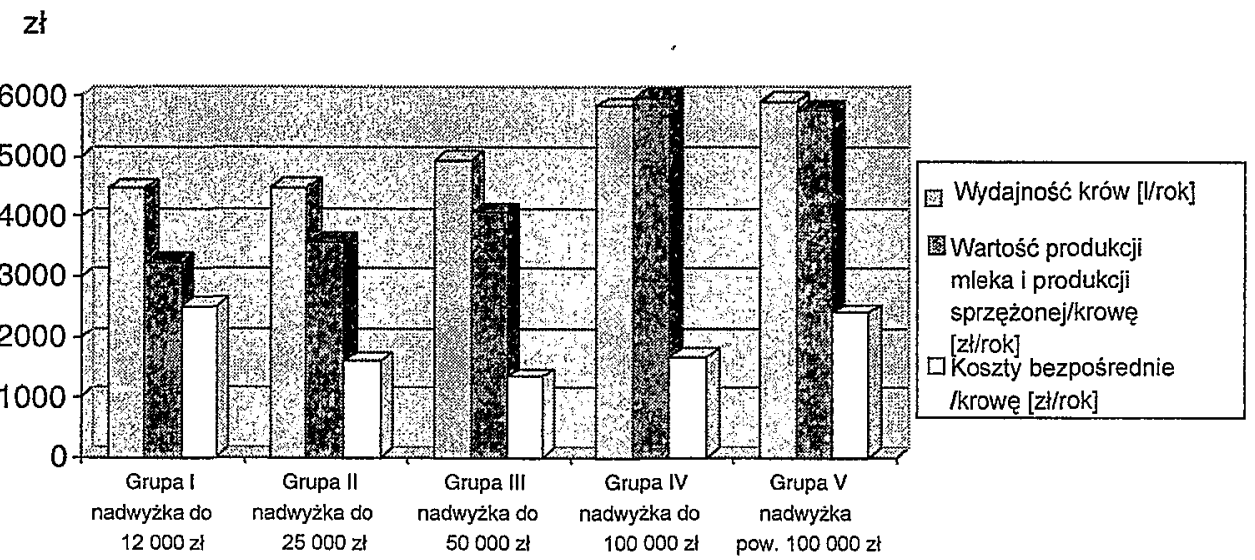

\section{Rysunek 1}

Ważniejsze wskaźniki związane ze skalą produkcji mleka Źródło: Badania własne. 
Odmienna sytuacja była $\mathrm{w}$ grupie $\mathrm{V}$ : gospodarstw, funkcjonujących na bazie gospodarstw uspołecznionych, gdzie utrzymywano od 42 do 173 krów mlecznych. Osiągały one największą wartość nadwyżki bezpośredniej, ale opłacalność bezpośrednia spadła do średniego poziomu rzędu 2,41.

$Z$ danych IERiGŻ wynika [Skarżyńska, Pokrzywa, Augustyńska-Grzymek 2000, 2002], że średnie rzeczywiste koszty pośrednie w gospodarstwach utrzymujących krowy wynosiły w latach 1997-2001 41-49\% kosztów bezpośrednich, a amortyzacja majątku trwałego związanego z produkcją mleka stanowiła około $50 \%$ kosztów bezpośrednich. W związku z tym, jeśli nawet pomniejszymy opłacalność bezpośrednią o $100 \%$, to znaczy o 1 , to gospodarstwa grupy $\mathrm{V}$ osiagały opłacalność produkcji mleka na poziomie dającym jeszcze realne możliwości zwiększenia nadwyżki bezpośredniej.

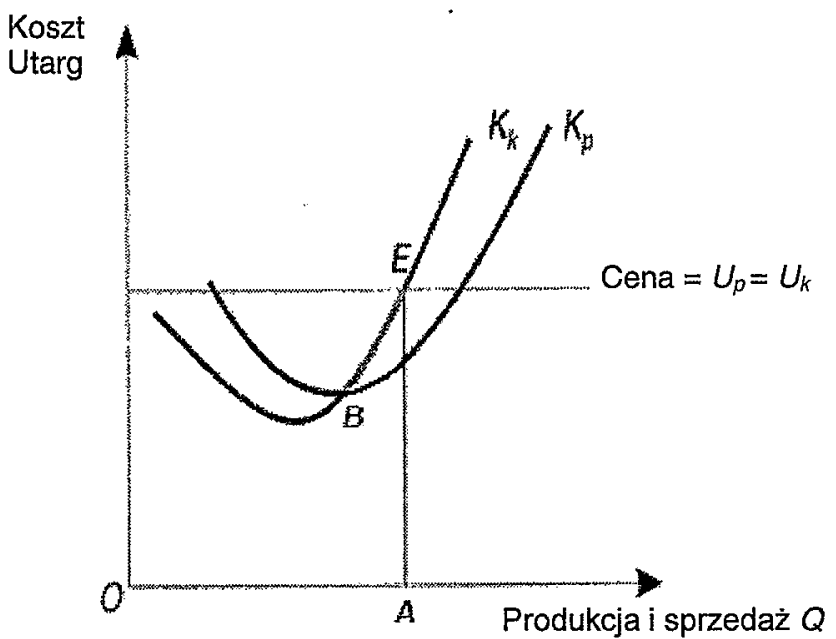

\section{Rysunek 2}

Koszty krańcowe mleka w badanych gospodarstwach uspołecznionych lub funkcjonujących na ich bazie (B-E)

Zródło: Badania własne.

W związku z tym należy przyjąć, że koszt krańcowy był wyższy od kosztu przeciętnego (odcinek BE na rys. 2), ale jednocześnie był niższy od ceny skupu. Oznacza to, że w gospodarstwach grupy V nadwyżka krańcowa była większa od zera, istniała zatem możliwość zwiększenia nadwyżki bezpośredniej, ale przy jednoczesnym dalszym pogorszeniu przeciętnej opłacalności produkcji mleka. 


\section{Liczba utrzymywanych krów mlecznych a opłacalność produkcji i nadwyżka bezpośrednia}

Przeciętna liczba krów mlecznych w badanych gospodarstwach zwiększała się. W 1997 r. wynosiła ona 17,3 sztuki, w 1998 - 17,4, w $1999-17,9$; w 2000 - 19,6, a w 2001 roku 19,7 sztuki. Przyrost liçzby krów mlecznych w porównaniu do 1997 r. wyniósł w kolejnych latach $0,58 \%, 3,47 \%, 13,29 \%$ i 14,16\%. Największy przyrost nastapił w 2000 r., co było związane z wyraźnym wzrostem cen skupu mleka, najmniejszy był natomiast w 1998 r., kiedy to wprowadzono wyższe wymagania jakościowe mleka na podstawie PN A-86002 „Mleko surowe do skupu”.

W latach 1997-2001 badane gospodarstwa mleczne posiadały od 11 do 173 krów. Pogarszanie za sprawą byłych gospodarstw uspołecznionych opłacalności bezpośredniej wraz ze wzrostem liczby krów potwierdza statystyka matematyczna (tab. 2). Współzmienność między skalą produkcji mierzoną liczbą krów w gospodarstwie a opłacalnością bezpośrednią była istotna, współczynniki korelacji brutto wynosily bowiem od $\mathrm{r}=-0,2671 \mathrm{w} 1997 \mathrm{r}$. do $\mathrm{r}=-0,3880$ w 1999 r. Zwiększenie stada o 1 krowę mleczną w gospodarstwie pogarszało wskaźnik opłacalności bezpośredniej od 0,0105 w 1997 r. do 0,017 w 2000 r.

\section{Tabela 2}

Modele regresji prostoliniowej opłacalności bezpośredniej względem skali produkcji mierzonej liczbą krów w gospodarstwie

\begin{tabular}{|l|c|c|c|c|c|}
\hline \multirow{2}{*}{ Nazwa zmiennej } & \multicolumn{5}{|c|}{ Wartość parametrów w latach } \\
\cline { 2 - 6 } & 1997 & 1998 & 1999 & 2000 & 2001 \\
\hline $\begin{array}{l}\text { Wartość stała } \\
\text { równania }\end{array}$ & 2,9498 & 3,4569 & 3,5224 & 34,9861 & 3,0226 \\
\hline $\begin{array}{l}\text { Wspólczynnik } \\
\text { regresji brutto }\end{array}$ & $-0,0105$ & $-0,0146$ & $-0,0169$ & $-0,0170$ & $-0,0106$ \\
\hline $\begin{array}{l}\text { Wspólczynnik kore- } \\
\text { lacji brutto }\end{array}$ & $-0,2671$ & $-0,3322$ & $-0,3880$ & $-0,3549$ & $-0,3162$ \\
\hline $\begin{array}{l}\text { Wartość testu } \\
\text { t-Studenta }\end{array}$ & $-3,4505$ & $-4,3846$ & $-5,2419$ & $-4,7266$ & $-4,1503$ \\
\hline $\begin{array}{l}\text { Wartość testu } \\
\text { F Snedecora }\end{array}$ & 11,9062 & 19,2244 & 27,4780 & 22,3403 & 17,2247 \\
\hline
\end{tabular}

Wartości krytyczne współczynnika korelacji brutto dla poszczególnych poziomów ufności wynosza: dla $\alpha=0,05 r=0,1519$, a dla $\alpha=0,01 r=0,2081$. Wartości krytyczne testu $t$-Studenta wynoszą odpowiednio: dla $\alpha=0,05 t=1,960$, a dla $\alpha=0,01 t=2,576$. Wartości krytyczne testu $F$ wynosza: dla $\alpha=0,05 F=3,06$, a dla $\alpha=0,01 F=4,75$. Źródło: Badania własne. 
Rosnąca stała równania w latach 1997-2000 wskazuje ogólnie na polepszające się warunki zwiększania stad i produkcji mleka, a jej spadek w $2001 \mathrm{r}$. świadczy o pogorszeniu się tych warunków, głównie z powodu spadku cen skupu mleka. Wartość bezwzględna testu t-Studenta we wszystkich latach badań była większa od wartości krytycznej, a zatem liczba krów była ważnym czynnikiem wpływającym na opłacalność bezpośrednią produkcji mleka. Związek ten nie był przypadkowy, statystka obserwowana $F$ we wszystkich latach badań była większa niż wartość krytyczna dla $\alpha=0,05$ wynosząca 3,06 .

Współzmienność między skalą produkcji mierzoną liczbą krów w gospodarstwie a nadwyżką bezpośrednią była bardzo silna, współczynniki korelacji brutto wynosily od $\mathrm{r}=0,7727 \mathrm{w} 1997$ roku do $\mathrm{r}=0,8885 \mathrm{w} 2000 \mathrm{r}$. (tab. 3). Zwiększenie stada o 1 krowę mleczną $w$ gospodarstwie średnio zwiększało nadwyżkę bezpośrednią od $1225 \mathrm{zł} \mathrm{w} 1999$ r. do 2262 zł w 2000 r. Wartość bezwzględna testu t-Studenta we wszystkich latach badań była większa od wartości krytycznej, a zatem liczba krów była ważnym czynnikiem wpływającym na wielkość nadwyżki bezpośredniej z produkcji mleka w gospodarstwie.

\section{Tabela 3}

Modele regresji prostoliniowej nadwyżki bezpośredniej względem skali produkcji mierzonej liczbą krów w gospodarstwie

\begin{tabular}{|l|c|c|c|c|c|}
\hline \multirow{2}{*}{ Nazwa zmiennej } & \multicolumn{5}{|c|}{ Wartość parametrów w latach } \\
\cline { 2 - 6 } & 1997 & 1998 & 1999 & 2000 & 2001 \\
\hline $\begin{array}{l}\text { Wartość stała } \\
\text { równania }\end{array}$ & 14444,00 & 19115,81 & 26557,50 & 24525,2 & 17091,70 \\
\hline $\begin{array}{l}\text { Współczynnik } \\
\text { regresji brutto }\end{array}$ & 1286,56 & 1523,02 & 1224,85 & 2261,85 & 1986,49 \\
\hline $\begin{array}{l}\text { Współczynnik } \\
\text { korelacji brutto }\end{array}$ & 0,7727 & 0,7942 & 0,7798 & 0,8885 & 0,8429 \\
\hline $\begin{array}{l}\text { Wartość testu } \\
\text { t-Studenta }\end{array}$ & 15,1527 & 16,2737 & 15,5067 & 24,1110 & 19,5036 \\
\hline $\begin{array}{l}\text { Wartość testu } \\
\text { F Snedecora }\end{array}$ & 229,6055 & 264,63 & 240,4579 & 581,34 & 380,39 \\
\hline
\end{tabular}

Wartości krytyczne parametrów pod tabelą 2.

Źródło: Badania własne.

\section{Ilość wyprodukowanego mleka a opłacalność i nadwyżka bezpośrednia}

Skalę produkcji mleka w gospodarstwie można mierzyć także ilością wyprodukowanego surowca. Ten sposób nie uwzględnia jakości produktu i w efekcie nie wiadomo, czy producent wykorzystuje możliwości ekonomiczne 
wynikające $\mathrm{z}$ wysokiej jakości $\mathrm{i}$ uzyskiwania najwyższej $\mathrm{z}$ tego tytułu ceny skupu. Niemniej jednak należy się zgodzić z tym, że ilość wyprodukowanego w ciagu roku mleka świadczy o skali produkcji w gospodarstwie. Uwzględniając wszystkie badane gospodarstwa, $\mathrm{w}$ ciagu pięciu lat wyprodukowały one przeciętnie 98944 litry mleka.

Współzmienność ilości wyprodukowanego mleka i opłacalności bezpośredniej dla poziomu ufności przy $\alpha=0,05$ była we wszystkich latach badań statystycznie istotna (tab. 4). Należy dodać, że w 1997 r. dla $\alpha=0,01$ współzmienność ta nie była istotna. Również dla wyższego poziomu ufności wartości obserwowane testów t i F były mniejsze od wartości krytycznych. Ogólnie mogło to oznaczać, że w pierwszym roku badań wzrost ilości produkowanego mleka w badanych gospodarstwach posiadających bardzo duże stada krów najmniej pogarszał opłacalność jego produkcji.

\section{Tabela 4}

Modele regresji prostoliniowej opłacalności bezpośredniej względem skali produkcji mierzonej ilością wyprodukowanego mleka w gospodarstwie

\begin{tabular}{|l|c|c|c|c|c|}
\hline \multirow{2}{*}{ Nazwa zmiennej } & \multicolumn{5}{|c|}{ Wartość parametrów w latach } \\
\cline { 2 - 6 } & 1997 & 1998 & 1999 & 2000 & 2001 \\
\hline $\begin{array}{l}\text { Wartość stała } \\
\text { równania }\end{array}$ & 2,8963 & 3,3886 & 3,5224 & 3,9482 & 2,9990 \\
\hline $\begin{array}{l}\text { Współczynnik } \\
\text { regresji brutto }\end{array}$ & $-1,4557$ & $-1,9979$ & $-2,5542$ & $-2,6979$ & $-1,7506$ \\
\hline $\begin{array}{l}\text { Współczynnik kore- } \\
\text { lacji brutto }\end{array}$ & $-0,2051$ & $-0,2660$ & $-0,3503$ & $-0,3671$ & $-0,3370$ \\
\hline $\begin{array}{l}\text { Wartość testu } \\
\text { t-Studenta }\end{array}$ & $-2,6090$ & $-3,4354$ & $-4,6556$ & $-4,9140$ & $-4,4557$ \\
\hline $\begin{array}{l}\text { Wartość testu } \\
\text { F Snedecora }\end{array}$ & 6,8069 & 19,2244 & 21,6745 & 24,1471 & 19,8533 \\
\hline
\end{tabular}

Wartości krytyczne parametrów pod tabelą 2.

Źródło: Badania własne.

Biorąc pod uwagę współczynnik regresji, zwiększenie produkcji o 100 tys. litrów pogarszało wskaźnik opłacalności bezpośredniej $w$ kolejnych latach: o 1,46 w 1997 r., o 1,99 w 1998, o 2,55 w 1999, o 2,70 w 2000 i o 1,75 w 2001 r. Ogólnie jednak, z uwagi na większą wartość stałej równania od wartości bezwzględnej współczynnika regresji, można uznać, że warunki do zwiększania ilości produkowanego mleka były korzystne, a opłacalność produkcji na skutek wzrostu ilości produkowanego mleka odzwierciedla zróżnicowanie wewnątrz badanej populacji gospodarstw na rodzinne gospodarstwa rolne i byłe lub w dalszym ciagu gospodarstwa uspołecznione. 
Współzmienność między skalą produkcji mierzoną ilością wyprodukowanego mleka w gospodarstwie a nadwyżką bezpośrednią była istotna, współczynniki korelacji brutto wynosiły od $r=0,7680 \mathrm{w} 1997 \mathrm{r}$. do $\mathrm{r}=0,9438$ w 2000 r. (tab. 5). Zwiększenie produkcji mleka o 1 litr zwiększało nadwyżkę bezpośrednią od $0,20 \mathrm{zl}$ w $1999 \mathrm{r}$. do $0,37 \mathrm{zl} \mathrm{w} 2000 \mathrm{r}$. Wartości bezwzględne testów t-Studentá i $\mathrm{F}$ we wszystkich latach badań były większe od wartości krytycznej.

\section{Tabela 5}

Modele regresji prostoliniowej nadwyżki bezpośredniej względem skali produkcji mierzonej ilością wyprodukowanego mieka w gospodarstwie

\begin{tabular}{|l|c|c|c|c|c|}
\hline \multirow{2}{*}{ Nazwa zmiennej } & \multicolumn{5}{|c|}{ Wartość parametrów w latach } \\
\cline { 2 - 6 } & 1997 & 1998 & 1999 & 2000 & 2001 \\
\hline $\begin{array}{l}\text { Wartość stała } \\
\text { równania }\end{array}$ & 16332,14 & 21103,73 & 28571,48 & 28517,21 & 20677,11 \\
\hline $\begin{array}{l}\text { Współczynnik } \\
\text { regresji brutto }\end{array}$ & 0,2299 & 0,2625 & 0,2046 & 0,3690 & 0,3373 \\
\hline $\begin{array}{l}\text { Współczynnik } \\
\text { korelacji brutto }\end{array}$ & 0,7680 & 0,8041 & 0,7784 & 0,9438 & 0,9202 \\
\hline $\begin{array}{l}\text { Wartość testu } \\
\text { t-Studenta }\end{array}$ & 14,9296 & 16,8420 & 15,4390 & 35,5713 & 29,2592 \\
\hline $\begin{array}{l}\text { Wartość testu } \\
\text { F Snedecora }\end{array}$ & 222,8951 & 263,6544 & 238,362 & 1265,3204 & 856,1031 \\
\hline
\end{tabular}

Wartości krytyczne parametrów pod tabelą 2.

Źródło: Badania własne.

\section{Produkcja towarowa mleka a opłacalność i nadwyżka bezpośrednia}

Uwzględniając wszystkie badane gospodarstwa w ciągu pięciu lat, roczna wartość produkcji towarowej mleka z gospodarstwa wyniosła przeciętnie 77,4 tys. zł. Współzmienność między wartością produkcji towarowej mleka a opłacalnością bezpośrednią była dla poziomu ufności przy $\alpha=0,05$ we wszystkich latach badań statystycznie istotna (tab. 6). Współczynnik korelacji brutto (r) wynosił od $-0,1881$ w 1997 r. do $-0,3593$ w 2000 r. Zatem współzmienność była najsilniejsza w roku, w którym obowiązywała najwyższa cena skupu. 
Tabela 6

Modele regresji prostoliniowej opłacalności bezpośredniej względem skali produkcji mierzonej wartością produkcji towarowej mleka z gospodarstwa

\begin{tabular}{|l|c|c|c|c|c|}
\hline \multirow{2}{*}{ Nazwa zmiennej } & \multicolumn{5}{|c|}{ Wartość parametrów w latach } \\
\cline { 2 - 6 } & 1997 & 1998 & 1999 & 2000 & 2001 \\
\hline $\begin{array}{l}\text { Wartość stała } \\
\text { równania }\end{array}$ & 2,8633 & 3,3741 & 3,4710 & 3,9466 & 2,9839 \\
\hline $\begin{array}{l}\text { Współczynnik } \\
\text { regresji brutto }\end{array}$ & $-1,9588$ & $-2,5362$ & $-3,4854$ & $-2,9744$ & $-1,8721$ \\
\hline $\begin{array}{l}\text { Współczynnik } \\
\text { korelacji brutto }\end{array}$ & $-0,1881$ & $-0,2475$ & $-0,3398$ & $-0,3593$ & $-0,3245$ \\
\hline $\begin{array}{l}\text { Wartość testu } \\
\text { t-Studenta }\end{array}$ & $-2,3849$ & $-3,1799$ & $-4,4979$ & $-4,7930$ & $-4,2709$ \\
\hline $\begin{array}{l}\text { Wartość testu } \\
\text { F Snedecora }\end{array}$ & 5,6880 & 10,1112 & 20,2310 & 22,9728 & 18,2404 \\
\hline
\end{tabular}

Wartości krytyczne parametrów pod tabelą 2.

Źródło: Badania własne.

Należy dodać, że w 1997 r. dla poziomu ufności przy $\alpha=0,01$ współzmienność ta nie była istotna. Również dla wyższego poziomu ufności wartości obserwowane testów t i F były mniejsze od wartości krytycznych. W 1997 r. odnotowano najmniejszą współzmienność między wartością produkcji towarowej mleka a osiaganym poziomem wskaźnika opłacalności bezpośredniej. W ogólnej populacji badanych gospodarstwach wzrost wartości produkcji mleka o 100 tys. zł powodował zmniejszenie wskaźnika opłacalności bezpośredniej od 1,87 w 2001 r. do 3,49 w 1999 r., co może świadczyć o tym, że największe gospodarstwa, produkujące relatywnie drogo, chcąc zwiększyć opłacalność produkcji, powinny zmniejszyć jej wartość przy jednocześnie większym obniżeniu kosztów.

Współzmienność między skalą produkcji mierzoną wartością produkcji towarowej mleka a nadwyżką bezpośrednią była istotna, współczynnik korelacji brutto wynosił od $\mathrm{r}=0,7732 \mathrm{w} 1997 \mathrm{r}$. do $\mathrm{r}=0,9429 \mathrm{w} 2000 \mathrm{r}$. (tab. 7).

Zwiększenie wartości produkcji towarowej mleka o 1 zł zwiększało nadwyżkę bezpośrednią: o 0,347 zł w 1997 r., o 0,355 zł w 1998, o 0,285 zł w 1999 , o 0,413 zł w 2000 r. i $0,375 \mathrm{zł} \mathrm{w} 2001$ r. Wartość bezwzględna testów t-Studenta i $\mathrm{F}$ we wszystkich latach badań była większa od wartości krytycznej. 


\section{Tabela 7}

Modele regresji prostoliniowej nadwyżki bezpośredniej względem skali produkcji mierzonej wartością produkcji towarowej mleka z gospodarstwa

\begin{tabular}{|l|c|c|c|c|c|}
\hline \multirow{2}{*}{ Nazwa zmiennej } & \multicolumn{5}{|c|}{ Wartość parametrów w latach } \\
\cline { 2 - 6 } & 1997 & 1998 & 1999 & 2000 & 2001 \\
\hline $\begin{array}{l}\text { Wartość stała } \\
\text { równania }\end{array}$ & 17805,22 & 22703,58 & 28868,71 & 29266,81 & 23280,28 \\
\hline $\begin{array}{l}\text { Współczynnik } \\
\text { regresji brutto }\end{array}$ & 0,3471 & 0,3550 & 0,2849 & 0,4131 & 0,3753 \\
\hline $\begin{array}{l}\text { Współczynnik } \\
\text { korelacji brutto }\end{array}$ & 0,7732 & 0,8047 & 0,7788 & 0,9429 & 0,9264 \\
\hline $\begin{array}{l}\text { Wartość testu } \\
\text { t-Studenta }\end{array}$ & 15,1794 & 16,8765 & 15,4550 & 35,2457 & 30,6361 \\
\hline $\begin{array}{l}\text { Wartość testu } \\
\text { F Snedecora }\end{array}$ & 230,4131 & 284,8173 & 238,8564 & 1242,26 & 938,5676 \\
\hline
\end{tabular}

Wartości krytyczne parametrów pod tabelą 2.

Źródło: Badania własne.

\section{Produkcja towarowa mleka wraz z produkcją sprzężoną a opłacalność}

We wszystkich badanych gospodarstwach w ciagu pięciu lat roczna wartość produkcji potencjalnie towarowej mleka i produkcji sprzężonej $\mathrm{z}$ gospodarstwa wyniosła przeciętnie 96,7 tys. zł. Zarówno gospodarstwa o najniższej, jak i o najwyższej opłacalności bezpośredniej miały zbliżoną wartość potencjalnie towarowej mleka $\mathrm{i}$ towarów sprzężonych $\mathrm{w}$ przeliczeniu na krowę mleczną. W latach 1997-2001 wynosiła ona w gospodarstwach o najniższej i najwyższej opłacalności $5400-5500$ zł na rok. Jednak duże gospodarstwa, funkcjonujace na bazie byłych gospodarstw państwowych lub spółdzielczych, produkowały intensywnie, ale drogo. Tradycyjne gospodarstwa indywidualne wraz ze wzrostem produkcji potencjalnie towarowej mleka i produkcji sprzężonej osiagały coraz lepszq̨ oplacalność. Uwzględniając powyższe, należy uznać, że nie wystarczy produkować dużo, trzeba jeszcze przy tym produkować relatywnie tanio, a zatem klucz do wzrostu opłacalności produkcji mleka leży $\mathrm{w}$ badanych gospodarstwach po stronie racjonalizacji kosztów bezpośrednich.

Współzmienność między wartością produkcji towarowej mleka i produkcji sprzężonej a opłacalnościa bezpośrednia była dla poziomu ufności przy $\alpha=0,05$ we wszystkich latach badań statystycznie istotna (tab. 8). Współzmienność była najsilniejsza w 2000 r., kiedỷ obowiązywała najwyższa cena 
skupu. Należy dodać, że w $1997 \mathrm{r}$. dla poziomu ufności przy $\alpha=0,01$ współzmienność ta nie była istotna. Również dla wyższego poziomu ufności wartości obserwowane testów t i F były mniejsze od wartości krytycznych. W $1997 \mathrm{r}$. zaobserwowano najmniejszą współzmnienność między wartością produkcji mleka i produkcji sprzężonej a osiaganym poziomem wskaźnika opłacalności bezpośredniej. W ogólnej populacji badanych gospodarstwach wzrost wartości tej produkcji o 100 tys. zł powodował zmniejszenie wskaźnika opłacalności bezpośredniej od 1,59 w 1997 r. do 3,03 w 1999 r.

\section{Tabela 8}

Modele regresji prostoliniowej opłacalności bezpośredniej względem skali produkcji mierzonej wartością produkcji potencjalnie towarowej mleka i produkcji sprzężonej

\begin{tabular}{|l|c|c|c|c|c|}
\hline \multirow{2}{*}{ Nazwa zmiennej } & \multicolumn{5}{|c|}{ Wartość parametrów w latach } \\
\cline { 2 - 6 } & 1997 & 1998 & 1999 & 2000 & 2001 \\
\hline $\begin{array}{l}\text { Wartość stała } \\
\text { równania }\end{array}$ & 2,8697 & 3,3716 & 3,4632 & 3,9411 & 2,9823 \\
\hline $\begin{array}{l}\text { Współczynnik } \\
\text { regresji brutto }\end{array}$ & $-1,5946$ & $-2,2704$ & $-3,0322$ & $-2,6892$ & $-1,6964$ \\
\hline $\begin{array}{l}\text { Współczynnik ko- } \\
\text { relacji brutto }\end{array}$ & $-0,1651$ & $-0,2430$ & $-0,3315$ & $-0,3518$ & $-0,3182$ \\
\hline $\begin{array}{l}\text { Wartość testu } \\
\text { t-Studenta }\end{array}$ & $-2,0840$ & $-3,1186$ & $-4,3738$ & $-4,6797$ & $-4,1789$ \\
\hline $\begin{array}{l}\text { Wartość testu } \\
\text { F Snedecora }\end{array}$ & 5,6879 & 9,7256 & 19,1304 & 21,8992 & 17,4631 \\
\hline
\end{tabular}

Wartości krytyczne parametrów pod tabelą 2.

Żródło: Badania własne.

Współzmienność między skalą produkcji mierzoną wartością produkcji towarowej mleka $\mathrm{z}$ gospodarstwa i produkcji sprzężonej a nadwyżką bezpośrednią była istotna, współczynniki korelacji brutto wynosiły od $\mathrm{r}=0,7872$ $\mathrm{w} 1999 \mathrm{r}$. do $\mathrm{r}=0,9498 \mathrm{w} 2000 \mathrm{r}$. (tab. 9). Zwiększenie wartości produkcji towarowej mleka i produkcji sprzężonej o 1 zł zwiększało nadwyżkę bezpośrednią: o $0,17 \mathrm{zł} w$ latach $1997-1998$, o $0,25 \mathrm{zł} \mathrm{w} 1999$ r., o 0,39 zł w $2000 \mathrm{r}$. i o $0,35 \mathrm{zł}$ w $2001 \mathrm{r}$. Wartość bezwzględna testów t-Studenta i F we wszystkich latach badań była większa od wartości krytycznej.

Warto jednak zauważyć, że współczynniki regresji brutto we wszystkich latach badań tylko dla wartości produkcji mleka były wyższe niż dla wartości produkcji mleka i produkcji sprzężonej. Świadczy to o celowości produkcji jałówek hodowlanych i cieląt, gdyż zwiększa to nadwyżkę bezpośrednią, ale pogarsza opłacalność produkcji omawianej działalności w gospodarstwie. 


\section{Tabela 9}

Modele regresji prostoliniowej nadwyżki bezpośredniej względem skali produkcji mierzonej wartością produkcji potencjalnie towarowej mleka i produkcji sprzężonej

\begin{tabular}{|l|c|c|c|c|c|}
\hline \multirow{2}{*}{ Nazwa zmiennej } & \multicolumn{5}{|c|}{ Wartość parametrów w latach } \\
\cline { 2 - 6 } & 1997 & 1998 & 1999 & 2000 & 2001 \\
\hline $\begin{array}{l}\text { Wartość stała } \\
\text { równania }\end{array}$ & 18853,94 & 21539,86 & 27627,33 & 27512,11 & 21528,73 \\
\hline $\begin{array}{l}\text { Współczynnik } \\
\text { regresji brutto }\end{array}$ & 0,1689 & 0,1730 & 0,2596 & 0,3862 & 0,3506 \\
\hline $\begin{array}{l}\text { Współczynnik } \\
\text { korelacji brutto }\end{array}$ & 0,7893 & 0,8168 & 0,7872 & 0,9498 & 0,9320 \\
\hline $\begin{array}{l}\text { Wartość testu } \\
\text { t-Studenta }\end{array}$ & 16,00 & 17,62 & 15,89 & 37,78 & 32,00 \\
\hline $\begin{array}{l}\text { Wartość testu } \\
\text { F Snedecora }\end{array}$ & 256,10 & 310,68 & 252,62 & 1427,58 & 1024,21 \\
\hline
\end{tabular}

Wartości krytyczne parametrów pod tabelą 2.

Żródło: Badania własne.

Uwzględniając poszczególne miary skali produkcji oraz uzyskane wyniki badań, należy stwierdzić, że opłacalność bezpośrednia w latach 1997-1999 była najbardziej skorelowana $\mathrm{z}$ liczbą krów w gospodarstwie, wskaźnik determinacji wynosił odpowiednio: $7,13 \%, 11,04 \%$ i $15,05 \%$. Z kolei $w$ latach 2000-2001 opłacalność bezpośrednia była najbardziej skorelowana z ilością wyprodukowanego mleka, która wyjaśniała odpowiednio $13,47 \%$ oraz $11,36 \%$ zmienności opłacalności produkcji. Na podstawie powyższych danych, jak i danych zawartych w tabeli 1 należy uznać, że gospodarstwa uspołecznione lub powstałe na ich bazie produkowały mleko intensywnie, po wysokich kosztach krańcowych.

\section{Podsumowanie}

W latach 1997-2001 w typowych gospodarstwach rodzinnych makroregionu środkowego wraz ze wzrostem skali produkcji, mierzonej: liczbą krów mlecznych, roczną produkcją mleka, wartością towarową mleka oraz wartością towarową mleka wraz z produkcją sprzężoną rosła zarówno opłacalność produkcji, jak i roczna nadwyżka bezpośrednia z produkcji mleka. A zatem istnieje celowość dalszej intensyfikacji produkcji mleka w tych gospodarstwach.

Gospodarstwa obszarowo duże (uspolecznione lub funkcjonujące na ich bazie) utrzymywały od 42 do 173 krów mlecznych. Osiągały one największą wartość nadwyżki bezpośredniej spośród wszystkich badanych gospodarstw, 
ale przeciętna opłacalność bezpośrednia $\mathrm{w}$ tej grupie była relatywnie niska $(2,41)$. Mimo uwzględnienia rzeczywistych kosztów pośrednich oraz amortyzacji, osiagany poziom opłacalności dawał jeszcze możliwości wzrostu nadwyżki bezpośredniej. Oznacza to, że koszt krańcowy był wyższy od kosztu przeciętnego, ale jednocześnie był niższy od ceny skupu, to znaczy nadwyżka krańcowa była większa od zera. Zwiększanie nadwyżki bezpośredniej w tych gospodarstwach było możliwe, ale wiązałoby się $\mathrm{z}$ dalszym pogorszeniem przeciętnej opłacalności produkcji mleka.

Uwzględniając poszczególne miary skali produkcji oraz uzyskane wyniki, należy stwierdzić, że w latach 1997-1999 opłacalność bezpośrednia była najbardziej ujemnie skorelowana z liczbą krów w gospodarstwie, wskaźnik determinacji wynosił odpowiednio: $7,13 \%, 11,04 \%$ i $15,05 \%$. $Z$ kolei $w$ latach 2000-2001 opłacalność bezpośrednia była najbardziej ujemnie skorelowana z ilością wyprodukowanego mleka, która wyjaśniała odpowiednio $13,47 \%$ oraz $11,36 \%$ zmienności opłacalności produkcji. Gospodarstwa uspołecznione lub powstałe na ich bazie produkowały mleko równie intensywnie jak najlepsze gospodarstwa rodzinne, ale po wyższych kosztach.

\section{Literatura}

KLEPACKI B., 1990: Organizacyjne i ekonomiczne uwarunkowania postępu technologicznego $w$ gospodarstwach indywidualnych (na przykładzie produkcji roślinnej). Wydawnictwo SGGW, Warszawa.

KLEPACKI B., 1997: Sytuacja ekonomiczna gospodarstw chłopskich w okresie transformacji. Zagadnienia Ekonomiki Rolnej, ar 2-3, Warszawa.

OKULARCZYK S., NOVAK T., BRZAZGACZ M., 1996: Nakłady robocizny w produkcji mleka i żywca wołowego. Zagadnienia Ekonomiki Rolnej, nr 2-3, Warszawa.

SKARŻYŃSKA A., POKRZYWA T., AUGUSTYŃSKA-GRZYMEK I., 2000, 2002 : Produkcja, koszty ekonomiczne i dochody wybranych produktów rolniczych w latach 2000-2001. IERiGŻ, Warszawa.

ZALEWSKI A., 2000: Gospodarka mleczarska a rynek. IERiGŻ, Warszawa.

\section{The Scale and the Profitability of Milk Production}

\section{Abstract}

In years 1997-2001 in the typical family farms of the Central Macro region with the growth of production scale measured by: numbers of milk cows, milk production per year and commodity value of milk production with coupled pro- 
duction - the profitability of milk production and direct surplus from milk production grew. It is useful to intensify the milk production in those farms.

State owned farms had from 42 to 173 milk cows. They achieved the highest direct surplus among the researched farms but average direct profitability fell to 2,41 . In spite of taking into consideration the real indirect costs and the depreciation of farms' costs, the achieved profitability still gave the possibility of the growth of direct surplus. It means that a margin cost was higher than an average cost and simultaneously was smaller than purchase price, and that a margin surplus was higher than zero. The increasing of the direct surplus in these farms was possible but connected with a further decreasing of average profitability of milk production.

Taking into the consideration the individual measure of the production scale and results received the direct profitability was the most negative correlated with the number of cows in the farm between 1997 and 1999: the index of determination was: $7,19 \%, 11,04 \%$ and $15,05 \%$. Between 2000 and 2001 the direct profitability was the most negative correlated with amount of produced milk, which explained $13,47 \%$ and $11,36 \%$ changeability of the profitability of the production. The direct surplus in the analysed period was the most correlated with the value of commodity milk production and coupled production. Therefore when one wants to achieve high direct surplus from researched farms one should produce milk of the highest quality and also produce and sell with profit not only calves and defective cows but also farm heifers.

In the analysed period the value of milk production and coupled production explained: $62,30 \% ; 66,72 \% ; 61,97 \% ; 90,21 \%$ and $86,86 \%$ of direct surplus changeability. 
